\title{
КУЛЬТУРНОЕ ПРОСТРАНСТВО АРХЕОЛОГИЧЕСКИХ КУЛЬТУР ЭПОХИ БРОНЗЫ ЮЖНОГО ПРИУРАЛЬЯ
}

\author{
Владимир Степанович Горбунов \\ Башкирский государственный педагогический университет им. М.Акмуллы, Уфа, Россия \\ E-mail: GVS1946@yandex.ru \\ Юрий Владимирович Горбунов \\ Институт развития образования РБ, Уфа, Россия \\ E-mail: yu.gorbunov2012@ yandex.ru
}

\begin{abstract}
Аннотация. Статья посвящена рассмотрению проблемы соотношения культурного пространства археологических культур и ареалов археологических культур на примере такого крупного региона, как Южное Приуралье. Авторы исходят из того, что ареал археологической культуры представляет собой пространство с физическими границами, где преимущественно преобладают эндогенные процессы. Культурное же пространство археологической культуры, по существу, представляет собой виртуальное пространство, функциональные границы которого могут многократно превосходить физические границы культуры. Обоснование данного подхода рассматривается на материалах абашевской культурноисторической общности. Абашевская КИО, как известно, имеет не сплошной, а мозаичный ареал, который представлен тремя входящими в него культурами: доно-волжской, средневолжской и уральской. При этом дискуссионной остается проблема их хронологического статуса. Существуют разные точки зрения на «первородность» каждой из них. Наряду с мнением о более раннем характере доно-волжских древностей, имеются сторонники, рассматривающие в качестве таковых средневолжские и уральские памятники. Однако, при всех упомянутых сложностях, влияние и воздействие абашевской КИО на ряд археологических культур бронзового века отличается многообразием и глубиной воздействия. В виртуальном пространстве этой общности наблюдаются несколько механизмов воздействия: от заимствования и внедрения технико-технологических процессов до включения целого ряда социокультурных основ абашевских племен как доноров, в качестве инновационных для реципиентов. Таким образом, изучение культурного пространства культур абашевской общности актуализирует необходимость формирования более детальных оценок историко-культурных процессов в лесостепи Евразии в эпоху бронзы.
\end{abstract}

Ключевые слова: Южное Приуралье, абашевская, срубная, алакульская культуры, синташтинскоаркаимская группа памятников, ареал археологических культур, культурное пространство археологических культур

Цитирование. Горбунов В.С., Горбунов Ю.В., 2021. Культурное пространство археологических культур эпохи бронзы Южного Приуралья // Уфимский археологический вестник. Т. 21, № 2. С. 215-221. DOI: https://doi.org/10.31833/uav/2021.21.2.003

UDC 902.01

Submitted: 30.09 .2021

LBC $63.4(2 \Gamma)$

Accepted: 18.10 .2021

\section{CULTURAL SPACE OF THE BRONZE AGE ARCHAEOLOGICAL CULTURES IN THE SOUTHERN CIS-URALS}

\author{
Vladimir S. Gorbunov \\ Bashkir State Pedagogical University named after M. Akmulla, Ufa, Russia \\ E-mail: GVS1946@yandex.ru \\ Yuri V. Gorbunov \\ Education development institute of the Republic of Bashkortostan, Ufa, Russia \\ E-mail: yu.gorbunov2012@yandex.ru
}

\begin{abstract}
The Abashevo cultural and historical communion is believed to be one of the most geographically and culturally significant formations of the Bronze Age in forest-steppe Eurasia. This communion is characterized by a mosaic area of distribution and includes three archaeological cultures, distinguished by their territory of residence i.e. the Don-Volga culture, the Mid-Volga culture and the Ural culture. By now, various theories have been suggested concerning the origin of these cultures and their chronological status is still hotly debated. There is an opinion that the Don-Volga assemblages should be treated as the most ancient. However, some scholars advocate the idea that the Mid-Volga and the Ural findings are older than the Don-Volga ones. Despite the existing questions, the significant influence of the Abashevo cultural and historical communion on the number of the archaeological cultures of the Bronze Age is undeniable. Each of the three cultures, constituting the communion, has their own documented limits of distribution. Besides real area of distribution, every culture also has a virtual space, characterized by its own influence. Thus, in the west the aforementioned influence led to the emersion of archaeological sites of the Pokrovka and Potapovka types. In the east, it resulted in the appearance
\end{abstract}


of the Sintashta-Petrovka archaeological sites. The virtual space of the communion is characterised by a number of impact mechanisms, from borrowing and adopting processing techniques to introducing a range of social and cultural principles of the Abashevo tribes, which served as donors, to their numerous recipients. Therefore, the study of the cultural space of the Abashevo cultural and historical communion results in the need to make more detailed assessments of historical and cultural process in the forest-steppe Eurasia in the Bronze Age.

Keywords: Southern Cis-Urals, Abashevo culture, Srubnaya culture, Alakul culture, Sintashta-Arkaim group of sites, area of distribution of archaeological cultures, cultural space of archaeological cultures

Citation. Gorbunov V., Gorbunov Yu., 2021. Cultural space of the Bronze Age archaeological cultures in the Southern Cis-Urals. Ufimskij arkheologicheskiy vestnik [The Ufa Archaeological Herald]. Vol.21, no.2, pp.215-221. (In Russ.). DOI: https://doi.org/10.31833/uav/2021.21.2.003

\section{Введение}

В самом общем виде у всякой археологической культуры ареал, как правило, очерчивается пунктами географического расположения памятников, относимых к данной культуре. Некоторые исследователи вполне обоснованно рассматривают археологическую культуру (АК) как систему открытую, где все её материальные и духовные компоненты сложным образом связаны информационными потоками с окружающим миром [Ковалевская, 1991. С.51], Это положение, в известной степени, можно отнести к сути понимания культурного пространства археологической культуры. При этом конфигурация культурного пространства АК зачастую выходят далеко за пределы границ распространения ареалов её памятников. Однако многократно отмечалось, что наибольшая мощность, глубина воздействия и проникновения культурных традиций часто прослеживается в местах соприкосновения разных культур. Остановимся на содержании понятия «пространство».

\section{Понятие «пространство»}

В современной географической науке активно разрабатываются проблемы пространственного анализа, соединяющие компьютерное моделирование с пространственной эконометрикой и математической статистикой. Данное сочетание позволяет вывести политическую и социально-экономическую географию на новый аналитический уровень обобщений [Окунев, 2020].

С позиции теоретической культурологии, пространство является жизненной и социокультурной сферой общества, «вместилищем» культурных процессов и, по сути, одним из главных факторов человеческого бытия [Теория культуры, 2008. С. 246]. С.Н.Иконникова с соавторами отмечают, «что культурное пространство - это поле, порождаемое взаимодействиями и воздействиями, ценностями культур и их систем». Ценности же культуры, по их мнению, представляются как специфические отношения между людьми, которые воплощаются и определяются в различных носителях и создают своеобразную духовную атмосферу [Теория культуры, 2008. С.247]. С этим доводом трудно не согласиться, но в археологических источниках проследить эти процессы практически невозможно. Несомненный интерес, в этой связи, имеют представления о том, что культурное пространство всегда существует как «дробное множество», которое способствует выполнению собирательной функции. Хотя, возможна и другая мо- дель, когда происходит процесс уменьшения силы притяжения между регионами, делая их обособленными и замкнутыми. Нельзя не согласиться и с тем, что через понятие культурного пространства может просматриваться как историческая преемственность, непрерывность, так и дискретность в историко-культурных процессах любой исторической эпохи [Теория культуры, 2008. С. 249].

С.К.Бондырева и Д.В.Колесов рассматривают пространство как обобщенное понятие протяженности материальных тел и расстояний между ними. Они считают, что у материального тела есть занимаемое им физическое пространство и образуемое им виртуальное пространство (курсив наш - В.Г., Ю.Г.). Если физическое пространство, по их мнению, имеет четкие границы, то, виртуальное пространство - это расстояние между материальным телом и объектами его взаимодействия [Бондырева, Колесов, 2004. С. 6-7]. В связи с этим они различают физическую и функциональную границы. Физическая граница - это зона, где завершается материальная протяженность объекта, взаимодействующего только с самим собой, за которой начинается свободное пространство. Функциональная же граница - это зона, в пределах которой проявляется возможность (способность) объекта воздействовать на другие объекты. Естественно, функциональная граница всегда превосходит размерами физическую границу. Этим, по существу, авторы различают понятия терминов «территория» и «сфера влияния» [Бондырева, Колесов, 2004. С. 7]. Данные подходы являются весьма ценными.

В отечественной археологической терминологии основными дефинициями для обозначения пространственного размещения археологических свидетельств в рамках конкретных ареалов археологических культур или культурно-исторических общностей, чаще всего выступают археологическая культура, ареал археологических памятников, культурно-историческая общность и историкокультурная область.

В этой связи, по нашему мнению, является целесообразным введение понятия пространства археологической культуры. При этом, вероятно, следует развести и уточнить понятия - ареал археологической культуры (или культурно-исторической общности) и культурное пространство археологической культуры (или культурно-исторической общности). 
Все рассмотренные выше рассуждения вполне применимы к объяснению процессов взаимодействия археологических культур и уточнению отдельных аспектов культурогенеза в эпоху бронзы лесостепной части Северной Евразии. В этой связи, заслуживает внимания использование в данном подходе разделение культур - на культуры доноров и культуры реципиентов [Арутюнов, 1989. С. 17-40].

\section{Обсуждение результатов}

Одной из крупных и значимых явлений бронзового века лесостепной Евразии является абашевская культурно-историческая общность. Территория ее распространения характеризуется отсутствием сплошного ареала. А.Д.Пряхин в рамках абашевской общности выделил и обосновал три входящих в нее родственные культуры - доноволжскую, средневолжскую и уральскую [Пряхин, $1976 ; 1977 ; 1980]$. Хотя на карте в обобщающей статье по абашевской культурно-исторической общности она выглядит вроде как целостная территория, на деле ареал общности носит мозаичный характер. Каждая из культур общности, соответственно, имеет этнографические отличия в деталях материальной культуры, в том числе в керамике. И это вполне объяснимо, так как у каждой из трех культур было разное этнокультурное окружение, и, вследствие контактов с соседями, естественно формировались особые синкретические признаки в рамках культурных традиций населения разных культур абашевской общности. Несмотря на наличие мозаичности ареала абашевской культурно-исторической общности в её материальной культуре отчетливо просматриваются основные, общие культурообразующие признаки. Вместе с тем, культурное пространство общности, по всей видимости, выходило далеко за пределы границ каждой из входящих в неё культур. Именно этим можно объяснить причину выявления влияния абашевского населения на его соседей. Хорошо известны факты наличия следов абашевских культурных традиций на ряде памятников катакомбной, срубной, алакульской, синташтинской и других культур.

Еще более обобщенную картину для периода стабилизации Евразийской металлургической провинции (ЕАМП) обосновывает Е.Н. Черных. Он связывает это с возникновением двух громадных археологических общностей. На территории от Северного Причерноморья до Южного Урала - срубной общности, ареал памятников которой составлял 1,5-1,8 млн. км ${ }^{2}$. К востоку от Урала до Алтая и от лесостепи Западной Сибири вплоть до предгорий Копетдага сформировался блок гигантской андроновской общности, имевший площадь 2,5-3 млн. км². Это явление все чаще рассматривают в рамках срубно-андроновской общности (4-4,5 млн. км²). Последняя, при этом, поглотила предшествующую абашевско-синташтинскую общность [Черных, 2009. С. 253].

Рассматривая культурное пространство абашевской КИО, следует обратить внимание на два аспекта. Во-первых, каково виртуальное пространство у каждой входящей в неё культур - доно-волжской, средневолжской и уральской. Вовторых, несомненный интерес представляет комплекс эндогенных процессов в рамках культурного пространства всей общности и его влияние на окружающие культуры.

Самая западная из культур - доно-волжская. Термин предложен и обоснован во многих работах А.Д.Пряхина [Пряхин, 1976; 1977; 1980; Пряхин, Халиков, 1987; Пряхин, Беседин, Захарова, 2001]. Занимает юго-западную часть абашевской КИО. Охватывает территорию от верховьев Оки и Сейма на западе, до верховьев р. Самары и Кинель на востоке. Южная граница проходит условно по границе лесостепи и степи Восточноевропейской равнины. На севере региона она граничит с ареалом средневолжской абашевской культуры [Пряхин, 1976. Рис. 30; Пряхин, Халиков, 1987. Рис.23]. В бассейне Среднего Дона просматривается его центральная часть, где выявлены наиболее значимые памятники доно-волжской абашевской культуры. Во все стороны от центра её ареала фиксируется большое количество периферийных археологических объектов [Пряхин, Халиков, 1987. Рис. 23]. Эту картину можно рассматривать как некую сферу влияния центра - зону его культурного пространства (рис. $1, I$ ). Правда, остается весьма важный вопрос о путях освоения его доно-волжскими абашевцами. Это могло быть планомерное освоение прилегающих территорий по разным направлениям на протяжении длительного периода, а также достаточно динамичное освоение в результате миграционных процессов. В любом случае, на наш взгляд, рациональное выполнение любой из этих программ абашевского населения преобладало над спонтанными процессами.

Как самостоятельную абашевскую культуру открыл и выделил еще в первой четверти ХХ столетия на территории Среднего Поволжья В.Ф.Смолин (рис. 1, II). Уже тогда она вызвала серьезный интерес в археологии бронзового века в стране и за рубежом. Описанию и анализу этой культуры посвящено большое количество книг и публикаций, в результате чего создана обширная источниковая база и библиография [Кузьмина, 1992; Абашеская..., 2003; Пряхин, 2003. С. 61-64]. Особенностью этой культуры в Чувашско-Марийском Поволжье является наличие только курганных некрополей и отсутствие поселенческих памятников. Однако погребальный обряд, керамика и погребальный инвентарь стали эталонными признаками абашевской культуры. Эти признаки и до сих пор служат основаниями для оценки абашевских древностей. Бытует точка зрения о более раннем характере волго-уральских памятников [Кузьмина, 1992. С. 74-76].

Выделение абашевских древностей на Южном Урале связано с научной деятельностью К.В. Сальникова [Сальников, 1967]. В 70-е годы прошлого века А.Д.Пряхин обосновал существование абашевской культурно-исторической общности, в ко- 


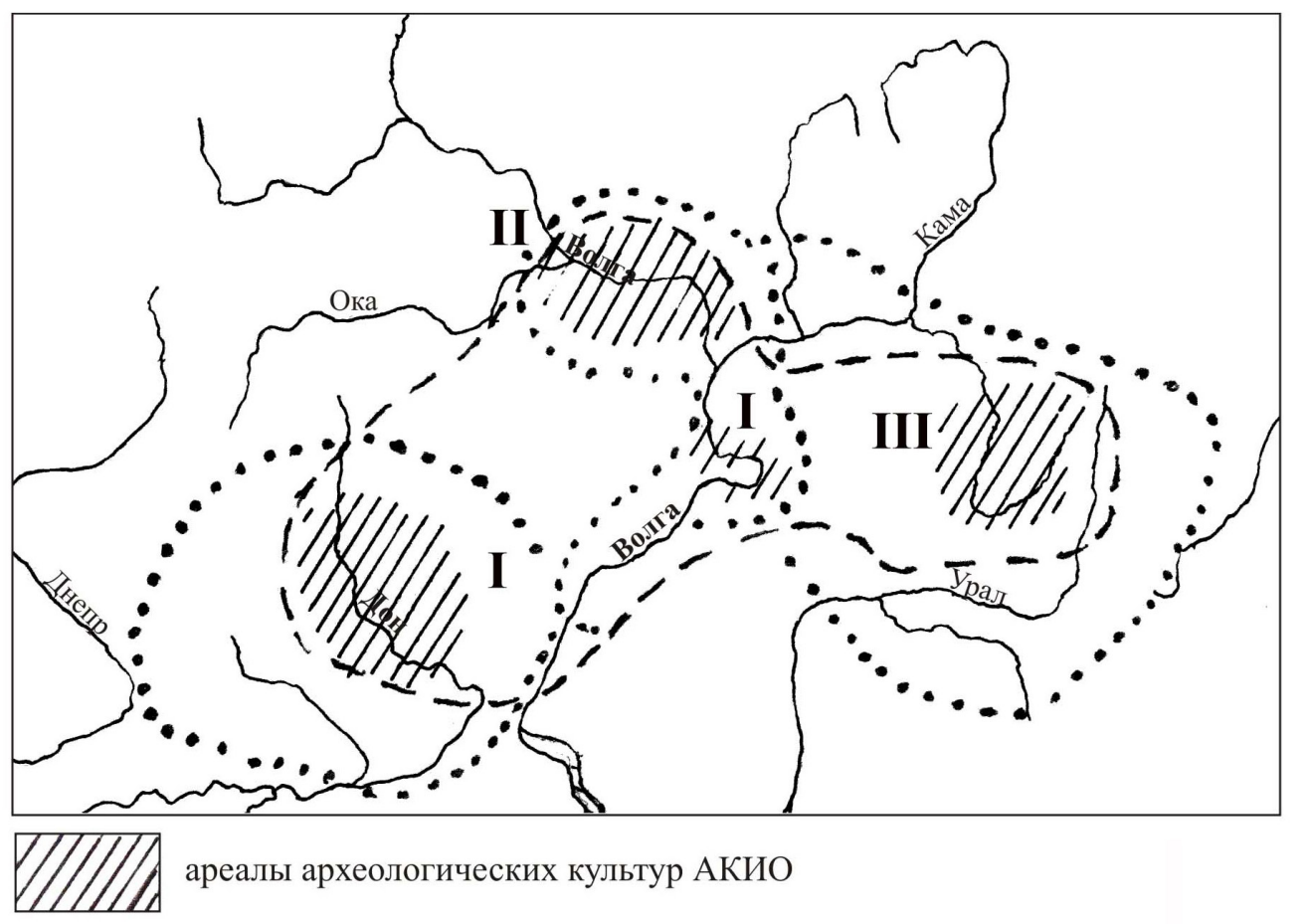

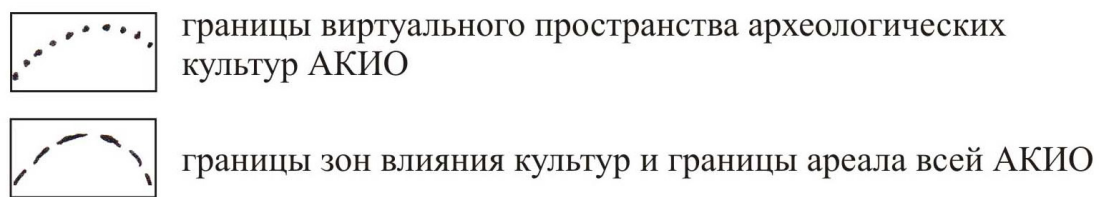

Рис. 1. Культурное пространство абашевской культурно-исторической общности (АКИО).

$I$ - доно-волжская абашевская культура; $I I$ - средневолжская абашевская культура; $I I I-$ уральская абашевская культура

Fig. 1. Cultural space of the Abashevo cultural and historical communion (ACHC).

I - Don-Volga Abashevo culture; II - Mid-Volga Abashevo culture; III - Ural Abashevo culture

торую наряду с доно-волжской и средневолжской была включена уральская абашевская культура [Пряхин, 1976, 1977; Пряхин и др., 2001] (рис. 1, III). К настоящему времени многие проблемы достаточно детально изучены, однако остается множество вопросов, возникших в процессе многократного увеличения источников по эпохе бронзы Евразии. Установлено влияние абашевской культуры на формирование срубных [Горбунов, 1992б; Синюк, 1996], алакульских [Потемкина, 1984. С. 77-108], синташтинских [Зданович, Малютина, 1996. С. 60-61, Епимахов, 2003. С. 133-137] древностей. Более того, А.В.Епимахов выделил несколько синхронных культур эпохи бронзы [Епимахов, 2010. С. 16]. Из них обратимся к двум первым парам - абашевская и синташтинская, срубная и алакульская археологические культуры. На основе радиоуглеродных дат А.В. Епимахов относит функционирование абашевско-синташтинского периода к XXI-XVIII вв. до н.э. (включая, кроме того, сюда же сейминско-турбинские древности), а срубно-андроновского периода - к XVIII-XV вв. до н.э. [Епимахов, 2010. С. 18].

Появление серьезных обобщающих исследований, основанных на анализе огромной массы археологических материалов, демонстрирует существенные достижения в области историко-археологической интерпретации процессов эпохи бронзы. Однако в отечественной археологической науке остается и преобладает использование ору- дийно-трудовой теории происхождения культуры. И это не случайно. Ведь в распоряжении археологов имеются артефакты, а также следы и остатки археологических памятников. Все же реальные следы хозяйственной, культурной, социальной и других аспектов реальной жизни нам недоступны. Поэтому, не случайно, что культурогенез любой археологической культуры (в нашем случае - эпохи бронзы) рассматривается, чаще всего, как фазы процесса смены одной археологической культуры другой или другими. В связи с этим представляет интерес мысль о том, что после выделения археологической культуры важное место занимают вопросы ее развития - генезис, расцвет, упадок и исчезновение. Фактически изучению подвергается вопрос о соотношении традиций и новшеств в развитии материальной и духовной культуры. В результате этого конфликта, по всей видимости, и происходит смена археологических культур [Алекшин, 1990. С. 125-126]. Однако А.В. Алекшин в понятие культурогенеза вкладывает создание детальной схемы культурогенеза Европы с неолита вплоть до письменного периода [Алекшин, 1990. C. 126].

Изучение виртуального пространства абашевской культурно-исторической общности позволяет предположить наличие нескольких вариантов воздействия абашевских племен на соседние этносы. Результатом первого пути является появление памятников, содержащих ряд синкретических 
артефактов, главным образом, в керамических коллекциях. Ярким примером служат материалы могильника Селезни 2, исследованного в Тамбовской области (бассейн р. Цны), где керамика представлена синкретическими образцами [Пряхин, Моисеев, Беседин, 1998. Рис. 4; 6; 9; 13]. На особенностях керамических комплексов Н.М. Малов рассматривает древности бронзового века Нижнего Поволжья как смену фаз покровской, срубной и хвалынской археологических культур [Малов, 2012]. Покровские древности он рассматривает как самостоятельный культурный тип абашевскосинташтинско-петровского блока культур [Малов, 1992. С. 15]. Так же достаточно отчетливо просматриваются абашевские заимствования в керамике и инвентаре на потаповских [Васильев, Кузнецов, Семенова, 1994. С.93-92], раннеалакульских [Потемкина, 1984. С. 77-108; Горбунов, 1992а. С. 181182], синташтинско-аркаимских [Епимахов, 2003. С. 133-137; Епимахов, Чуев, 2010. С. 141-143; Зданович, Малютина, 1996. С.60-61] памятниках. Созданный абашевцами высокоэффективный хозяйственно-культурный тип, в основе которого лежало полнопрофильное металлопроизводство и развитое скотоводство, выдвинуло население абашевско-синташтинской археологической общности на роль самого мощного очага культурогенеза периода средней бронзы европейской части Евразии [Горбунов Ю., Горбунов В., 2019. С. 113-114].

\section{Заключение}

Изучение виртуальных пространств археологических культур абашевской культурно-исторической общности открывает дополнительные перспективы в уточнении деталей и механизмов, связанных с процессами культурогенеза эпохи раннего палеометалла.
Абашевская культурно-историческая общность лесостепи Северной Евразии представляла собой мозаичный ареал родственных археологических культур, являвшихся, по сути, её достаточно самостоятельными историко-культурными частями. У каждой археологической культуры абашевской КИО просматривается своё историкокультурное окружение. В процессе историко-культурных контактов между ними были выявлены следы влияний и воздействий - как между разными группами абашевских племен, так и с окружавшим их массивом других культур. При этом, одной из самых сложных и нерешенных к настоящему времени проблем относится внутренняя хронология культур абашевской общности. Анализ современного состояния изученности абашевской проблематики создает представление о более раннем характере уральской и средневолжской культур по сравнению с доно-волжскими древностями. Основанием для этого суждения является наличие на памятниках Южного Приуралья как поселенческих, так и погребальных памятников, на которых просматриваются устойчивые культурообразующие признаки культуры, получившей в литературе название «абашевской». Уральские и средневолжские древности в материальной культуре имеют между собой самые близкие аналогии. Доно-волжские памятники в силу их отдаленности от восточных культур общности, вряд ли могли в процессе дрейфа на восток породить всю уникальность абашевских древностей. Видимо, именно уральские абашевцы оставили многочисленные и разнообразные следы взаимодействий с потаповскими, алакульскими и синташтинско-аркаимскими племенами Южного Урала и Среднего Поволжья.

\section{СПИСОК ЛИТЕРАТУРЫ}

Абашевская культурно-историческая общность: истоки, развитие, наследие. Материалы междунар. науч. конф. Чебоксары: ЧГИГН, 2003. $272 \mathrm{c}$.

Алёкшин В.А. Археология и проблемы культурогенеза // Археологические культуры и культурная трансформация: Материалы методич. семинара ЛОИА АН СССР / Отв. ред. В.М.Массон, В.Н.Боряз, М.В.Аникович. Л.: ЛВВИСКУ, 1991. C. $125-128$.

Арутюнов С.A. Народы и культуры. Развитие и взаимодействие. М.: Наука, 1989. 243 с.

Бондырева С.К., КолесовД.В. Миграция (сущность и явление): Учеб.-метод. пособие. Воронеж: МОДЭК, 2004. 294 c.

ВасильевИ.Б., КузнеиовП.Ф., СеменоваА.П. Потаповский курганный могильник индоиранских племен на Волге. Самара: Самарский университет, 1994. $207 \mathrm{c}$.

Горбунов В.С. Бронзовый век Волго-Уральской лесостепи. Уфа: БГПИ, 1992а. 223 с.

Горбунов В.С. Могильник бронзового века Ветлянка IV // Древняя история населения Волго-
Уральских степей / Отв. ред. А.Т.Синюк. Оренбург: ОПИ, 1992б. С. 166-194.

Горбунов Ю.В., Горбунов В.С. Металлургия и металлообработка племен уральской абашевской культуры. Уфа: БГПУ, 2019. 166 с.

Епимахов А.В. Об абашевском «наследии» в культурах поздней бронзы Урала // Абашевская культурно-историческая общность: истоки, развитие, наследие. Материалы междунар. науч. конф. Чебоксары: ЧГИГН, 2003. С. 133-137.

Епимахов А.B. Бронзовый век Южного Урала (экономический и социальный аспекты). Автореф. дисс. ... докт. ист. наук. Екатеринбург, 2010. 55 с.

Епимахов А.В., Чуев Н.И. Возможности пространственного анализа (абашевские и синташтинские памятники) // XVIII Уральское археологическое совещание: Культурные области, археологические культуры, хронология. Уфа: БГПУ, 2010. C. 141-143.

ЗдановичГ.Б., Малютина Т.С. Абашевская культура и синташтинский очаг культурогенеза // Абашевская культурно-историческая общность в системе древностей эпохи бронзы степи и лесо- 
степи Евразии: Тезисы докладов междунар. науч. конф. Тамбов, 1996. С. 60-61.

Ковалевская В.Б. Взаимосвязь понятий «археологическая культура» и «культурные традиции» // Археологические культуры и культурная трансформация: Материалы методич. семинара ЛОИА АН СССР / Отв. ред. В.М.Массон, В.Н.Боряз, М.В. Аникович. Л.: ЛВВИСКУ, 1991. С.48-51.

КузьминаО.В. Абашевская культура в лесостепном Волго-Уралье: Учебное пособие к спецкурсу. Самара: СГПИ, 1992. 128с.

Малов Н.М. «Абашевские племена» Нижнего Поволжья (Памятники покровского типа). Автореф. дисс. .... канд. ист. наук. СПб., 1992. 16 с.

Малов Н.M. Культурогенез в эпоху поздней бронзы Нижнего Поволжья // Известия Саратовского университета. Серия История. Международные отношения. 2012. Т. 12. С. 96-101.

Окунев И.Ю. Основы пространственного анализа. М.: Аспект Пресс, 2020. 255 с.

Потемкина T.M. Роль абашевцев в процессе развития алакульской культуры // Эпоха бронзы Восточно-европейской лесостепи / Отв. ред. А.Д. Пряхин. Воронеж: ВГУ, 1984. С. 77-108.

Пряхин А.Д. Поселения абашевской общности. Воронеж: ВГУ, 1976. 168 с.
Пряхин А.Д. Погребальные абашевские памятники. Воронеж: ВГУ, 1977. 165 с.

Пряхин А.Д. Абашевская культурно-историческая общность эпохи бронзы и лесостепь // Археология восточноевропейской лесостепи / Ред. А.Д. Пряхин. Воронеж: ВГУ, 1980. С. 7-32.

Пряхин А.Д., ХаликовА.Х. Абашевская культура // Эпоха бронзы лесной полосы СССР / Отв. ред. тома О.Н. Бадер, Д.А. Крайнов, М.Ф. Косарев. М.: Наука, 1987. С. 124-131. (Археология СССР).

ПряхинА.Д., МоисеевН.Б., Беседин В.И. Селезни-2. Курган доно-волжской абашевской культуры. Воронеж: ВГУ, 1998. 44 с.

Пряхин А.Д., Беседин В.И., З ЗахароваЕ.Ю., СаврасовА.С., СафоновИ.Е., СвистоваЕ.Б. Доно-волжская абашевская культура. Воронеж: ВГУ, 2001. 172 c.

Сальников К.В. Очерки древней истории Южного Урала. М.: Наука, 1967. 408 с.

Синюк А.T. Бронзовый век бассейна Дона. Воронеж: ВПУ, 1996. 350 с.

Теория культуры. Учебное пособие / Под ред. С.Н. Иконниковой, В.П.Большаковой. СПб.: Питер, 2008. 590 c.

Черных Е.Н. Степной пояс Евразии: Феномен кочевых культур. М.: Рукописные памятники Древней Руси, 2009. 622 с.

\section{REFERENCES}

"Abashevskaya kul'turno-istoricheskaya obshchnost': istoki, razvitie, nasledie. Materialy mezhdunar. nauch. konf", ("The Abashevo cultural and historical communion: its genesis, development and heritage. Proceedings of the International scientific conference"). Cheboksary, 2003, 272 p. (In Russ.)

Alyokshin, V.A. "Archaeology and the problems of the genesis of cultures", Arheologicheskie kul'tury $i$ kul'turnaya transformaciya: Materialy metodich. seminara LOIA AN SSSR ("Archaeological cultures and cultural transformations: Proceedings of the methods seminar of the Leningrad branch of the Institute of Archaeology of the Academy of Sciences of the USSR"). Leningrad, 1991, pp. 125-128. (In Russ.)

Arutyunov, S.A. 1989, "Peoples and cultures. Their development and interplay”. Nauka, Moscow, $243 \mathrm{p}$.

Bondyreva,S.K., Kolesov, D.V. 2004, "Migration (phenomenon and its essence): A student's handbook”. MODEK, Voronezh, 294p. (In Russ.)

Vasilev, I.B., Kuznetsov, P.F., \& Semenova,A.P. 1994, "Potapovka barrow necropolis of the Indo-Iranian tribes on the Volga river". Samarskij universitet, Samara, 207 p. (In Russ.)

Gorbunov, V.S. 1992, "The Volga-Ural forest-steppe in the Bronze Age”. BGPI, Ufa, 223 p. (In Russ.)

Gorbunov, V.S. "The Bronze Age necropolis Vetlyanka $4^{\text {th}}$,, Drevnyaya istoriya naseleniya VolgoUral'skih stepej ("Ancient history of inhabitants of the Volga-Ural steppe”). Orenburg, 1992, pp. 166-194. (In Russ.)
Gorbunov, Y.V., Gorbunov, V.S. 2019, "Metallurgy and metal processing of the Ural Abashevo culture tribes". BGPU, Ufa, 166p. (In Russ.)

Epimahov, A.V. "On the "heritage" of the Abashevo culture in the Late Bronze Age cultures of the Urals region", Abashevskaya kul'turno-istoricheskaya obshchnost': istoki, razvitie, nasledie. Materialy mezhdunar nauch. konf. ("The Abashevo cultural and historical communion: its genesis, development and heritage. Proceedings of the International scientific conference"). Cheboksary, 2003, pp. 133-137. (In Russ.)

Epimahov, A.V. 2010, "The Southern Ural in the Bronze Age (economic and cultural aspects). Dissertation abstract ... Doctor of Historical Sciences. Ekaterinburg, 55 p. (In Russ.)

Epimahov, A.V., Chuev, N.I. "Capabilities of the spatial analysis of the Abashevo and Sintashta sites", XVIII Ural'skoe arheologicheskoe soveshchanie: Kul'turnye oblasti, arheologicheskie kul'tury, hronologiya ("18 $18^{\text {th }}$ Ural Archaeological Conference: Cultural regions, archaeological cultures, chronology"). Ufa, 2010, pp. 141-143. (In Russ.)

Zdanovich, G.B., Malyutina, T.S. "The Abashevo culture and the Sintashta center of cultural genesis", Abashevskaya kul 'turno-istoricheskaya obshchnost'v sisteme drevnostej epohi bronzy stepi i lesostepi Evrazii: Tezisy dokladov mezhdunar. nauch. konf. ("The Abashevo cultural and historical communion in the system of the Bronze Age antiquities of steppe and forest-steppe Eurasia"). Tambov, 1996, pp.60-61. (In Russ.) 
Kovalevskaya, V.B. "Relations between the terms "archaeological culture" and "cultural traditions", $A r$ heologicheskie kul 'tury i kul 'turnaya transformaciya: Materialy metodich. seminara LOIA AN SSSR ("Archaeological cultures and cultural transformations: Proceedings of the methods seminar of the Leningrad branch of the Institute of Archaeology of the Academy of Sciences of the USSR"). Leningrad, 1991, pp.4851. (In Russ.)

Kuzmina, O.V. 1992, "The Abashevo culture in the forest-steppe Volga-Ural region: A student's handbook to the academic minor". SGPI, Samara, $128 \mathrm{p}$. (In Russ.)

Malov, N.M. 1992, "The Abashevo tribes of the Lower Volga region (The Pokrovka type archaeological sites). Dissertation abstract ... Candidate of Historical Sciences". Saint Petersburg, 16 p. (In Russ.)

Malov, N.M. 2012, "Genesis of cultures in the Late Bronze Age in the Lower Volga region", Izvestiya Saratovskogo universiteta. Seriya Istoriya. Mezhdunarodnye otnosheniya, vol. 12, pp.96-101. (In Russ.)

Okunev, I.Y. 2020, "The basics of spatial analysis”. Aspekt Press, Moscow, 255 p. (In Russ.)

Potemkina, T.M. "The role of the Abashevo peoples in the development of the Alakul culture", Epoha bronzy Vostochno-evropejskoj lesostepi ("The Bronze Age of the East European forest-steppe"). Voronezh, 1984, pp. 77-108. (In Russ.)

Pryahin,A.D. 1976, "The Abashevo communion settlements”. VGU, Voronezh, 168 p. (In Russ.)

Pryahin,A.D. 1977, "The Abashevo burial sites". VGU, Voronezh, 165 p. (In Russ.)
Pryahin,A.D. "The Abashevo cultural and historical communion of the Bronze Age and foreststeppe", Arheologiya vostochnoevropejskoj lesostepi ("Archaeology of the East European forest-steppe"). Voronezh, 1980, pp. 7-32. (In Russ.)

Pryahin,A.D., Halikov, A.H. "The Abashevo culture", Arheologiya SSSR: Epoha bronzy lesnoj polosy SSSR ("Archaeology of the USSR: The Bronze Age in the forest zone of the USSR"). Moscow, 1987, pp. 124-131. (In Russ.)

Pryahin,A.D., Moiseev, N.B., \& Besedin, V.I. 1998, "Selezni-2. A barrow of the Don-Volga Abashevo culture". VGU, Voronezh, 44 p. (In Russ.)

Pryahin,A.D., Besedin, V.I., \& Zaharova, E.Y., Savrasov,A.S., Safonov, I.E., Svistova, E.B. 2001, "The Don-Volga Abashevo culture". VGU, Voronezh, 172 p. (In Russ.)

Salnikov, K.V. 1967, "Essays on the Ancient History of the Southern Ural". Moscow: Nauka, 408p. (In Russ.)

Sinyuk,A.T. 1996, "The Don river basin in the Bronze Age”. VPU, Voronezh, 350 p. (In Russ.)

Bolshakov, V.P., Moskvina, I.K., \& Ikonnikova, S.N., Leleko, V.D., Makhlina, S.T., Ostrovskaya, E.A., Ostrovskaya, E.P., Petrov,L.V., Prokudenkova, V.V., Selivanov, V.V., Skotnikova, G.V., Suvorov, Y.Y. 2008, "The theory of culture. A student's handbook". Piter, Saint Petersburg, 590p. (In Russ.)

Chernyh, E.N. 2009, "The steppe belt of Eurasia: Phenomenon of nomadic cultures". Rukopisnye pamyatniki Drevnej Rusi, Moscow, 622 p. (In Russ.)

\section{Сведения об авторах}

Владимир Степанович Горбунов, доктор исторических наук, профессор, Башкирский государственный педагогический университет им. М.Акмуллы, Российская Федерация, г.Уфа. E-mail: GVS1946@yandex.ru, ORCID: 0000-0002-0054-0555

Юрий Владимирович Горбунов, кандидат исторических наук, директор издательского центра, Институт развития образования РБ, Российская Федерация, г. Уфа. E-mail: yu.gorbunov2012@yandex.ru, ORCID: 0000-0002-3523-1365

\section{Information About the Authors}

Vladimir S. Gorbunov, Doctor of Historical Sciences, professor, Bashkir State Pedagogical University named after M. Akmulla, Russian Federation, Ufa. E-mail: GVS1946@yandex.ru, ORCID: 0000-0002-00540555

Yuri V. Gorbunov, Ph.D., head of the publishing office Education development institute of the Republic of Bashkortostan Russian Federation, Ufa. E-mail: yu.gorbunov2012@ yandex.ru, , ORCID: 0000-0002-35231365 